\section{Vine Removal Prior to Harvest, and Curing Duration and Temperature Affect the Incidence and Severity of Internal Necrosis in 'Covington' Sweetpotato}

\author{
Fernando Montero de Espinosa Baselga ${ }^{1}$, Jonathan R. Schultheis ${ }^{1}$, \\ Michael D. Boyette ${ }^{2}$, Lina M. Quesada-Ocampo ${ }^{3}$, \\ Keith D. Starke ${ }^{1}$, and David W. Monks ${ }^{1}$
}

AdDITIONAL INDEX WORDS. Ipomoea batatas, mowing, preharvest, postharvest, potassium fertilizer, storage, vine snatching

SUMMARY. Internal necrosis (IN) is a physiological disorder that affects Covington, the most commonly grown sweetpotato (Ipomoea batatas) cultivar in North Carolina. Because IN affects the quality of sweetpotato storage roots, studies have been conducted since the first report of IN in 2006. Field studies (three in 2016 and two in 2017) were conducted to evaluate preharvest and postharvest treatments on the occurrence of IN in 'Covington' storage roots. Four preharvest treatments consisted of combinations of high chlorine or minimal chlorine potash fertilizer and mowing vs. not mowing before harvest. For postharvest treatments, 30 storage roots were obtained at harvest from each preharvest treatment plot and immediately cured in 75 and $85{ }^{\circ} \mathrm{F}$ rooms for a duration of $0.5,1,2,3$, and 5 weeks in 2016 , and $0.5,1$, and 2 weeks in 2017 . Shorter curing durations ( 0.5 and 1 week) coincided with industry recommendations while longer durations mimicked the challenges that some commercial facilities face when cooling down temperatures of rooms after curing is supposed to be concluded. Once curing temperature and curing duration treatments were completed, roots were placed in a $58{ }^{\circ} \mathrm{F}$ storage room at $85 \%$ relative humidity until cut. A control comparison was included in which harvested roots were placed in a $58{ }^{\circ} \mathrm{F}$ storage room (no curing) immediately after harvest. The storage roots from all temperature treatments were then cut 49 to 80 days after harvest, and incidence and severity of IN visually rated. Preharvest potash fertilizer treatments had minimal or no effect on occurrence of IN. However, mowing vines before harvest in several studies reduced IN incidence when roots were cured for more than 0.5 week at temperatures of at least $75^{\circ} \mathrm{F}$. Lower temperature ( $75 \mathrm{vs} .85$ ${ }^{\circ} \mathrm{F}$ ) and shorter curing duration ( 0.5 vs. $1,2,3$, or 5 weeks) resulted in reduced IN occurrence in 'Covington' sweetpotato.

$\mathrm{N}$ orth Carolina produces more than $65 \%$ of sweetpotato $(I$. batatas) acreage in the United States, with 98,000 acres planted in 2019 (U.S. Department of Agriculture, 2020). Covington, released by North Carolina State University in 2005 (Yencho et al., 2008), is the most important cultivar grown in North Carolina and accounts for $\approx 90 \%$ ( $\approx 88,000$ acres $)$ of the commercial acreage across the state $(\mathrm{K}$. McIver, personal communication).

Approximately 1 year after ' $\mathrm{Cov}$ ington' was commercially available, a grower reported that 1600 tons of sweetpotato roots in storage had a disorder characterized by small brown to black necrotic areas in the flesh near the proximal end of the root, which is where storage roots are removed from the stem (Dittmar et al., 2018; Jiang et al., 2015; Schultheis et al.,
2009). This disorder has been named internal necrosis [IN (Clark et al., 2013b)].

Since initial reports in 2006, IN continues to be a concern across the sweetpotato industry in North Carolina. In surveys conducted in 2010 and 2011 , more than $90 \%$ of storage rooms surveyed (56 total) had some incidence of IN. Incidence of IN in most storage rooms was less than $10 \%$; however, in three cases incidence was greater than $30 \%$ (Jiang et al., 2015). After harvest, IN may develop and in some cases results in nonmarketable roots (Fig. 1). Even when IN is severe, it is present only in the first one-third to one-half of the root from the proximal end.

Research has been ongoing since 2006 to better understand IN. Sweetpotato cultivars differed in degree and severity of IN susceptibility, with Covington and Hatteras being the most susceptible (Clark et al., 2013a; Dittmar et al., 2010). Field studies also determined that IN is not transmitted from seed roots to transplants (Schultheis and Thornton, 2007). The hypothesis of any pathogens being associated with the occurrence of IN was discarded through serological, molecular, and grafting methods and Koch's Postulates (L.M. QuesadaOcampo, unpublished data). Additional field studies determined that IN was not associated with the use of insecticides (Jiang et al., 2015) or herbicides (Beam et al., 2017). These studies suggest that the cause of IN was not pesticide related and was not biological; rather, it appeared to be a physiological disorder that occurred in certain clones.

An ethephon compound (PREP; Bayer Crop Science, Research Triangle, NC) releases ethylene which is the active ingredient in several commercial products. Ethylene is commonly used as a defoliator in cotton (Gossypium hirsutum) and tobacco (Nicotiana tabacum) and has been evaluated as a chemical application to sweetpotato vines with the purpose of tightening the skin of the storage roots before harvest (Beam et al., 2017; Jiang et al., 2015; Main et al., 2009; Wang et al., 2012). Studies in 2010,2012 , and 2015 found that ethylene was associated in the development of IN in sweetpotatoes, with 'Covington' being the most susceptible clone (Arancibia et al., 2013;

\begin{tabular}{llll}
\hline $\begin{array}{l}\text { Units } \\
\begin{array}{l}\text { To convert U.S. to SI, } \\
\text { multiply by }\end{array}\end{array}$ & U.S. unit & SI unit & $\begin{array}{l}\text { To convert SI to U.S., } \\
\text { multiply by }\end{array}$ \\
\hline 0.4047 & $\mathrm{acre}(\mathrm{s})$ & $\mathrm{ha}$ & 2.4711 \\
0.3048 & $\mathrm{ft}$ & $\mathrm{m}$ & 3.2808 \\
2.54 & inch(es) & $\mathrm{cm}$ & 0.3937 \\
1.1209 & $\mathrm{lb} / \mathrm{acre}$ & $\mathrm{kg} \cdot \mathrm{ha}^{-1}$ & 0.8922 \\
1 & $\mathrm{ppm}$ & $\mu \mathrm{L} \cdot \mathrm{L}^{-1}$ & 1 \\
0.9072 & $\mathrm{ton}(\mathrm{s})$ & $\mathrm{Mg}$ & 1.1023 \\
$\left({ }^{\circ} \mathrm{F}-32\right) \div 1.8$ & ${ }^{\circ} \mathrm{F}$ & ${ }^{\circ} \mathrm{C}$ & $\left({ }^{\circ} \mathrm{C} \times 1.8\right)+32$
\end{tabular}




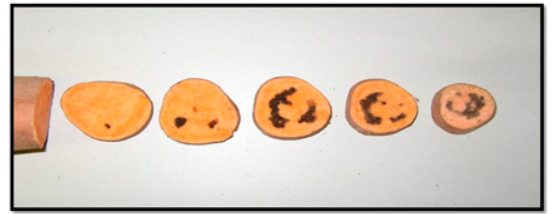

Fig. 1. Internal necrosis symptoms in a 'Covington' sweetpotato root that was cut from the proximal end of the root. Internal necrosis symptoms disappear and become less severe when slicing nears the center of the root.

Beam et al., 2017; Clark et al., 2013a; Dittmar et al., 2010; Jiang et al., 2015). Internal necrosis symptoms were exacerbated with the application of ethylene; however, ethylene was not solely associated with IN, as low incidence and less severe IN symptoms were also present when ethylene was not applied in 'Covington' (Dittmar et al., 2018).

Because the ethylene hormone has an important role in postharvest handling, a number of sweetpotato studies have focused on postharvest ethylene produced by the roots (Buescher et al., 1975; Kitinoja, 1987). Sweetpotatoes are very sensitive to ethylene in storage

Received for publication 14 May 2019. Accepted for publication 3 July 2020

Published online 7 August 2020

${ }^{1}$ Department of Horticultural Science, North Carolina State University, 2721 Founders Drive, Raleigh, NC 27695-7609

${ }^{2}$ Department of Biological and Agricultural Engineering, North Carolina State University, 3100 Faucette Drive, Raleigh, NC 27695-7625

${ }^{3}$ Department of Entomology and Plant Pathology, North Carolina State University, Raleigh, 2510 Thomas Hall, Raleigh, NC 27695-7616

We thank the North Carolina Agricultural Research Service, North Carolina Cooperative Extension Service, Golden Leaf Foundation, and Covington Endowment for the funds that supported this work. We also thank the North Carolina Sweet Potato Commission, Inc. for their financial support. We thank Hill Top Farm Service Center, Inc. and Warren Farms for providing fertilizer and/or serving as a host site for the field studies. We also acknowledge Joy Smith for conducting the statistical analysis. Finally, we acknowledge the support of personnel from the Horticultural Crops Research Station, Clinton, NC; the Cunningham Research Station, Kinston, NC; and the County Extension faculty who participated in conducting these research studies.

Mention of a trademark, proprietary product, or vendor does not constitute a guarantee or warranty of the product by North Carolina State University and does not imply its approval to the exclusion of other products or vendors that also may be suitable.

J.R.S. is the corresponding author. E-mail: jonr@ ncsu.edu.

This is an open access article distributed under the CC BY-NC-ND license (https://creativecommons.org/ licenses/by-nc-nd/4.0/).

https://doi.org/10.21273/HORTTECH04408-19 and can cause internal darkening and pithy areas (Edmunds et al., 2008). Exposure to $10 \mathrm{ppm}$ ethylene during or after curing enhanced respiration and polyphenol oxidase, as well as decreased attributes of color and flavor (Buescher et al., 1975). Even though sweetpotatoes are sensitive to ethylene exposure (Buescher et al., 1975), symptoms were not like those seen with IN damage. More recent studies evaluated the effect of a high concentration of ethylene gas (100 ppm) during curing and storage on IN incidence in 'Covington' sweetpotatoes (Jiang et al., 2015). These studies revealed IN incidence was unaffected by sampling date, year, or treatment with a high concentration of ethylene gas during sweetpotato storage. Only $4 \%$ of the roots from the studies had IN symptoms at the lowest level of severity. A sweetpotato storage disorder "hardcore" has some similarities with IN, such as blackened areas; however, the affected areas caused by chilling injury bleed across the entire length of the flesh and are diffuse compared with IN (Timbie and Haard, 1977).

In preliminary field studies that were not replicated, the effects of mowing the vines before harvest was investigated as a possible stressing factor that could contribute to the occurrence of IN. Also, muriate of potash [potassium chloride $(\mathrm{KCl})$ ], a fertilizer high in chloride content, was evaluated for its effect on IN in sweetpotatoes since tobacco growers have reported a reduction in the quality of flue-cured tobacco (Garner et al., 1930; McCants and Woltz, 1967: Skogley, 1962). This fertilizer is used as a source of potassium $(\mathrm{K})$ for both crops, which are grown extensively in North Carolina. To supply the K with low chloride content, many growers use potassium sulfate $\left(\mathrm{K}_{2} \mathrm{SO}_{4}\right)$. Another preliminary study that was not replicated evaluated numerous curing temperatures and time durations immediately after harvest on the occurrence and severity of IN. It was observed that IN incidence increased when roots were exposed to 75 or $85^{\circ} \mathrm{F}$ for 1 to 3 weeks of curing immediately after harvest vs. 0.5 week of curing.

As discussed earlier, many factors have been investigated and systematically eliminated or need further investigation as to the cause of IN in sweetpotatoes. Thus, the objective of these studies was to evaluate preharvest (potash fertilizer type and mowing vs. not mowing) and postharvest (curing temperature and curing duration) treatments on the occurrence of IN in 'Covington' storage roots.

\section{Materials and methods}

Three studies were conducted in 2016 at Hilltop Farms [HF (Middle Creek, NC: lat. $35^{\circ} 36^{\prime} 09.6^{\prime \prime} \mathrm{N}$, long. $78^{\circ} 43^{\prime} 20.5^{\prime \prime} \mathrm{W}$ )], Warren Farms [WF (Mt Olive, NC: lat. $35^{\circ} 13^{\prime} 31.9^{\prime \prime} \mathrm{N}$ long. $\left.\left.78^{\circ} 06^{\prime} 24.8^{\prime \prime} \mathrm{W}\right)\right]$, and the Cunningham Research Station [CRS (Kinston, NC: lat. $35^{\circ} 18^{\prime} 17.7^{\prime \prime} \mathrm{N}$, long. $\left.\left.77^{\circ} 34^{\prime} 52.5^{\prime \prime} \mathrm{W}\right)\right]$. Two studies were also conducted in 2017 at WF (Newton Grove, NC: lat. $5^{\circ} 14^{\prime} 18.3^{\prime \prime} \mathrm{N}$, long. $78^{\circ} 20^{\prime} 08.9^{\prime \prime} \mathrm{W}$ ) and CRS (Kinston, NC: lat. $35^{\circ} 17^{\prime} 58.5^{\prime \prime} \mathrm{N}$, long. $\left.77^{\circ} 34^{\prime} 25.3^{\prime \prime} \mathrm{W}\right)$. Studies at CRS were established with a tworow transplanter using transplants from seed increase beds at the Horticultural Crops Research Station, Clinton, NC. Studies at $\mathrm{HF}$ and WF were established with transplants and planting equipment from each respective farm. Transplant dates for the 2016 and 2017 studies were between late May and late June (Table 1), when most commercial sweetpotato acreage is planted (Kemble et al., 2016). Each study site had bedded rows 42 or 44 inches wide. The in-row crop spacing at all locations was 12 inches. Each plot consisted of eight rows $50 \mathrm{ft}$ long and $10-\mathrm{ft}$ alleys between the end and beginning of plots.

A randomized complete block design with four replications was used in the field for all studies in 2016 and 2017. A field replicate contained 32 planted rows of sweetpotatoes $50 \mathrm{ft}$ long with plants spaced 12 inches apart. Four plots comprised a replicate with a field plot being eight rows with $\approx 400$ plants. Layout of the field plots was the same in all studies. After harvest, treatments were a split-plot design and arranged in a $2 \times 2$ factorial, with main plots being preharvest treatments including post plant fertilizer (fert) $\times$ preharvest vine mowing (mow), and split-plot factors being postharvest treatments of curing temperature $(\mathrm{c}$ temp), and curing duration (c-weeks). 
Table 1. Critical preharvest cultural management practices for sweetpotato at an on-farm location in Middle Creek, NC (HF); an on-farm location in Newton Grove, NC (WF); and Cunningham Research Station in Kinston, NC (CRS) in 2016 and 2017.

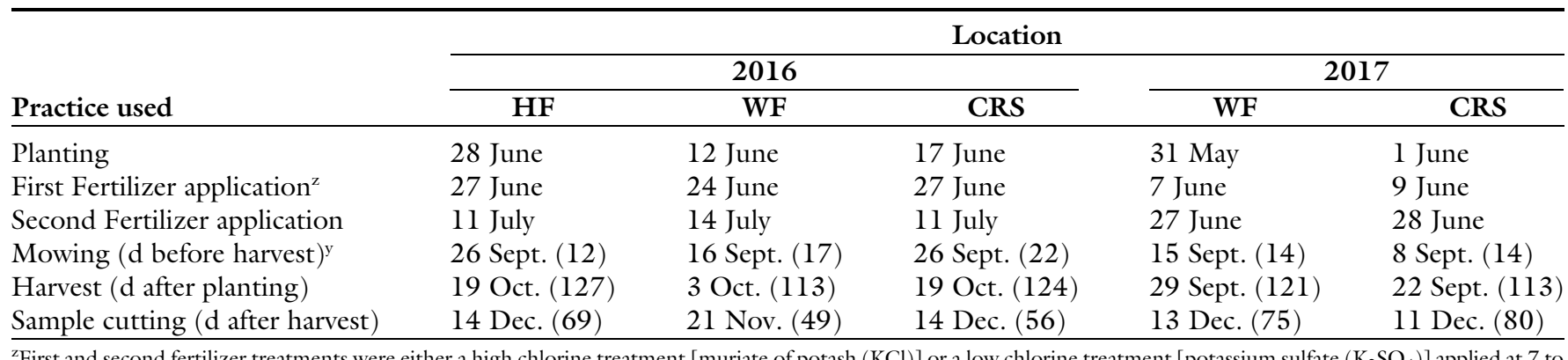

${ }^{\mathrm{z}}$ First and second fertilizer treatments were either a high chlorine treatment [ muriate of potash $\left.(\mathrm{KCl})\right]$ or a low chlorine treatment $\left[\right.$ potassium sulfate $\left.\left(\mathrm{K}_{2} \mathrm{SO} \mathrm{O}_{4}\right)\right]$ applied at 7 to $14 \mathrm{~d}$ after planting (first application) and 21 to $41 \mathrm{~d}$ after planting (second application).

${ }^{\mathrm{y}}$ Mowing treatments included the removal of plant foliage with a crop shredder 12 and $22 \mathrm{~d}$ before harvest in 2016 and $14 \mathrm{~d}$ before harvest in 2017 , or foliage was not removed until day of harvest.

Preharvest treatments. The two preharvest fert treatments consisted of using either $\mathrm{KCl}$ or $\mathrm{K}_{2} \mathrm{SO}_{4}$. Fertilizer treatments were sidedressed by hand, with each application consisting of $112.1 \mathrm{lb} /$ acre $\mathrm{K}(\mathrm{KCl}$ with $0 \mathrm{~N}-0 \mathrm{P}-49.8 \mathrm{~K}$ or $\mathrm{K}_{2} \mathrm{SO}_{4}$ with $0 \mathrm{~N}-$ $0 \mathrm{P}-41.5 \mathrm{~K}-17 \mathrm{~S})$. Fertilizer was applied at two different times, at 7 to $14 \mathrm{~d}$ and 21 to $41 \mathrm{~d}$ after planting (DAP) (Table 1 ) for a seasonal total of $224.1 \mathrm{lb} /$ acre $\mathrm{K}$. The high rate of $\mathrm{K}$ was applied to maximize the level of chlorine in $\mathrm{KCl}$ and to potentially illicit an $\mathrm{IN}$ response. $\mathrm{KCl}$ contains $45 \%$ to $47 \%$ chlorine (Mosaic Company, 2020), whereas $\mathrm{K}_{2} \mathrm{SO}_{4}$ contains low amounts of chlorine at no greater than $2.5 \%$ (Lee and Kpytowski, 1998). Elemental sulfur with analysis 0N-0P-0K-90S was applied during the two application times for a seasonal total of $46 \mathrm{lb} /$ acre to all $\mathrm{KCl}$ plots to provide an equivalent rate of sulfur to that contained in $\mathrm{K}_{2} \mathrm{SO}_{4}$. Fertilizers that contained basic macronutrients were applied to all plots and the common agricultural practices for 'Covington' sweetpotato were followed (Yencho et al., 2008). Two separate applications of calcium nitrate $\left[\mathrm{Ca}\left(\mathrm{NO}_{3}\right)_{2}\right]$ with an analysis $15.5 \mathrm{~N}-0 \mathrm{P}-0 \mathrm{~K}-19 \mathrm{Ca}$ were applied at a rate of $30 \mathrm{lb} /$ acre nitrogen $(\mathrm{N})$ to all plots for a seasonal total of $60 \mathrm{lb} /$ acre N. All plots received triple superphosphate $\left[\mathrm{Ca}\left(\mathrm{H}_{2} \mathrm{PO}_{4}\right]\right.$ with $0 \mathrm{~N}-20.1 \mathrm{P}-$ $0 \mathrm{~K}$ analysis at $13.1 \mathrm{lb} /$ acre phosphorus (P). Application timing of $\mathrm{P}$ coincided with the first $\mathrm{K}$ fertilizer application. Vine mowing treatments were included in the study and consisted of mowed and nonmowed plots. Mowing equipment was used to remove vines at each study location $\approx 2$ weeks before harvest (Table 1). A flail-type mower that shreds the foliage (Loffness, Hector, MN) was used at WF, a rotary-type mower (Bush Hog, Selma, AL) at HF, and a flail mower (Ma PF Oelwein, Oelwein, IA) at CRS.

Postharvest treatments. On the day of harvest [113 to 127 DAP (Table 1)], a total of 30 U.S. No. 1 roots were placed in sample bags from rows 3 to 7 of each plot. In 2016 , a total of 12 bags were collected and in 2017 only 8 bags were collected. For each 30-root sample bag, each of the 30 roots were obtained from a different plant. Sample bags collected from each plot were then subjected to curing times of $0.5,1,2,3$, and $5 \mathrm{c}$-weeks in 2016 and $0.5,1$, and 2 c-weeks in 2017; and c-temp treatments of 75 and $82^{\circ} \mathrm{F}$ in 2016, and 75 and $85{ }^{\circ} \mathrm{F}$ in 2017. Relative humidity (RH) each year was $85 \%$ as recommended (Edmunds et al., 2008). Once the c-temp and c-weeks treatments were achieved (i.e., $75^{\circ} \mathrm{F}$, 2 c-weeks), the sample roots were moved to a storage room with temperature set at $58{ }^{\circ} \mathrm{F}$ and $85 \% \mathrm{RH}$. An additional sample in which roots were not cured was placed in the storage room but was not a part of the experimental design and therefore not included in the statistical analysis. An extra sample of roots was collected from each plot and then cut in the field to see if any IN was present at harvest. Data loggers (HOBO UX100003; Onset Computer Corp., Bourne, MA) were placed in the curing/storage rooms both years to record $\mathrm{RH}$ (percent) and temperature $\left({ }^{\circ} \mathrm{F}\right)$.

Root samples from the studies were cut 49 to $80 \mathrm{~d}$ after harvest
(DAH) (Table 1). Beginning at the proximal end of the sweetpotato, 0.1 inch sections were cut until approximately one-half of the root remained. Incidence of IN was recorded as the percentage of 30 roots per bag (each bag was a replicate for a given treatment combination) that had any symptoms of IN. Severity was visually rated from the 0.1 -inch cross section with the highest necrotic area of each root with IN symptoms using a grading scale of 1 to 5 (Fig. 2). Previous research has shown that IN symptoms increase until $\approx 30 \mathrm{DAH}$ in 'Covington', but remains similar thereafter (Dittmar et al., 2018). Incidence of IN data was analyzed using Proc Mixed (SAS/STAT version 9.4 M3 for Windows; SAS Institute, Cary, NC) statistical analysis. Separation of significance between treatment means was conducted using the

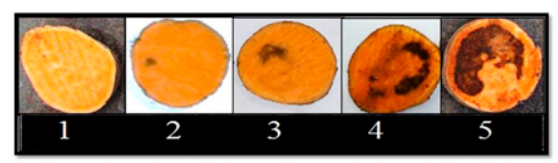

Fig. 2. Grading cards used for rating 'Covington' sweetpotato internal necrosis severity: 1 = no internal necrosis incidence; 2 = least severe and still marketable root, $<\mathbf{5 \%}$ necrotic; $\mathbf{3}=$ darker necrotic tissue with limited necrotic area and still marketable, $5 \%$ to $20 \%$ necrotic; $4=$ necrotic tissue covers $21 \%$ to $60 \%$ of the sampled root, darker color, not marketable; $5=$ necrotic tissue covers $>60 \%$ of the sample, dark and not marketable. Severity was determined using the cross section with the highest necrotic area of root. 
Tukey-Kramer procedure only when Proc Mixed was significant.

\section{Results and discussion}

The results are presented separately for 2016 and 2017 because responses for IN incidence differed between years for preharvest and postharvest treatments (Table 2). Although it appeared like IN severity was worse (Fig. 2) when IN incidence was higher, we were unable to document this relationship because there were minimal differences across treatments for IN severity. Because IN incidence better distinguished treatment differences than severity, only incidence of IN is presented.

It also should be noted that the $85^{\circ} \mathrm{F}$ c-temp treatment in 2016 was not attained even though the curing room was set at that temperature. The hobo units placed in the curing room measured an average of $\approx 82^{\circ} \mathrm{F}(81.8$ $\pm 3.0^{\circ} \mathrm{F}$ ) rather than the $85^{\circ} \mathrm{F}$ indicated by the computer display of the curing room. Thus, we reference the $85^{\circ} \mathrm{F}$ treatment in the 2016 studies as $82^{\circ} \mathrm{F}$. The $85^{\circ} \mathrm{F}$ room temperature in the 2017 studies $\left(83.6 \pm 0.4{ }^{\circ} \mathrm{F}\right)$ was closer to the targeted temperature

than in 2016. The standard deviation for the $75^{\circ} \mathrm{F}$ curing room was $73.4 \pm$ $3.6^{\circ} \mathrm{F}$ in 2016 and $76.7 \pm 0.8^{\circ} \mathrm{F}$ in 2017.

The amount of IN incidence that occurred in our studies is on par with what is often found commercially (Jiang et al., 2015). In 2010 and $2011,57 \%$ of commercial sweetpotato storage rooms surveyed had IN incidence that ranged from $1 \%$ to $10 \%$, whereas $27 \%$ had IN incidence that ranged between $11 \%$ and $30 \%$.

2016. Preharvest treatments mow and fert were not significant in the HF study (Table 2); however, the main effects of postharvest treatments (c-weeks and c-temp) affected the incidence of IN at $P \leq 0.001$ and 0.006 , respectively. Roots exposed to $82{ }^{\circ} \mathrm{F}$ had $12 \%$ IN incidence vs. $9 \%$ IN at $75^{\circ} \mathrm{F}$ (table not included). It should be noted that when roots were placed into a $58{ }^{\circ} \mathrm{F}$ storage room immediately after harvest and not exposed to curing or warmer temperatures, a 5\% IN incidence was recorded for the HF study (Table 3 ). Only $1 \%$ IN incidence occurred when roots were not cured in the WF study (Table 4). IN incidence was

Table 2. Type 3 tests of fixed effects in 2016 and 2017 for treatment main effects and interactions on the percentage incidence of internal necrosis in 'Covington' sweetpotatoes at an on-farm location in Middle Creek, NC (HF); an on-farm location in Newton Grove, NC (WF); and Cunningham Research Station in Kinston, NC (CRS).

\begin{tabular}{|c|c|c|c|c|c|c|}
\hline \multirow[b]{3}{*}{ Effect } & \multirow[b]{3}{*}{ df } & \multicolumn{5}{|c|}{$P$ value ${ }^{\mathrm{z}}$} \\
\hline & & \multicolumn{3}{|c|}{2016} & \multicolumn{2}{|c|}{2017} \\
\hline & & $\mathrm{HF}$ & WF & CRS & WF & CRS \\
\hline$M^{y}$ & 1 & 0.1 & 0.1 & 0.002 & 0.004 & 0.001 \\
\hline $\mathrm{F}^{\mathrm{x}}$ & 1 & 0.9 & 0.1 & 0.1 & 0.1 & 0.2 \\
\hline $\mathrm{M} \times \mathrm{F}$ & 1 & 0.7 & 0.3 & 0.1 & 0.2 & 0.8 \\
\hline $\mathrm{W}^{\mathrm{w}}$ & 4 & $<0.0001$ & $<0.0001$ & $<0.0001$ & $<0.0001$ & $<0.0001$ \\
\hline $\mathrm{M} \times \mathrm{W}$ & 4 & 0.7 & 0.4 & 0.002 & 0.001 & 0.02 \\
\hline $\mathrm{F} \times \mathrm{W}$ & 4 & 0.9 & 0.2 & 0.3 & 0.5 & 0.6 \\
\hline $\mathrm{M} \times \mathrm{F} \times \mathrm{W}$ & 4 & 0.6 & 0.3 & 0.1 & 0.2 & 0.02 \\
\hline $\mathrm{T}^{\mathrm{v}}$ & 1 & 0.006 & $<0.0001$ & $<0.0001$ & 0.02 & $<0.0001$ \\
\hline $\mathrm{M} \times \mathrm{T}$ & 1 & 0.2 & 0.5 & 0.005 & 0.2 & 0.007 \\
\hline $\mathrm{F} \times \mathrm{T}$ & 1 & 0.3 & 0.2 & 0.1 & 0.9 & 0.9 \\
\hline $\mathrm{M} \times \mathrm{F} \times \mathrm{T}$ & 1 & 0.8 & 0.6 & 0.04 & 0.3 & 0.5 \\
\hline $\mathrm{W} \times \mathrm{T}$ & 4 & 0.4 & 0.006 & 0.6 & 0.7 & 0.1 \\
\hline $\mathrm{M} \times \mathrm{W} \times \mathrm{T}$ & 4 & 0.4 & 0.9 & 0.6 & 0.3 & 0.6 \\
\hline$\underline{\mathrm{F} \times \mathrm{W} \times \mathrm{T}}$ & 4 & 0.5 & 0.2 & 0.6 & 0.2 & 0.9 \\
\hline
\end{tabular}

${ }^{\mathrm{z}} P$ values were significant at $\alpha \leq 0.05$. Separation of significance between treatment means was conducted using the Tukey-Kramer procedure only when Proc Mixed (SAS/STAT version 9.4 M3 for Windows; SAS Institute) was significant.

${ }^{\mathrm{y}}$ Mowing treatments $(\mathrm{M})$ : plant foliage was removed with a mower 12 and $22 \mathrm{~d}$ before harvest in 2016 and $14 \mathrm{~d}$ before harvest in 2017, or foliage was not removed until day of harvest.

${ }^{x}$ Fertilizer treatments $(\mathrm{F})$ : either a high chlorine treatment [muriate of potash $\left.(\mathrm{KCl})\right]$ or a low chlorine treatment [potassium sulfate $\left(\mathrm{K}_{2} \mathrm{SO}_{4}\right)$ ] were applied at 7 to $14 \mathrm{~d}$ and 21 to $41 \mathrm{~d}$ after planting.

${ }^{w}$ Weeks of curing $(\mathrm{W})$ : roots were cured for $0.5,1,2,3$, and 5 weeks in 2016 and $0.5,1$, and 2 weeks in 2017

vTemperature of curing $(\mathrm{T})$ : treatments were 75 and $82^{\circ} \mathrm{F}\left(23.9\right.$ and $\left.27.8^{\circ} \mathrm{C}\right)$ in 2016 and 75 and $85^{\circ} \mathrm{F}\left(29.4^{\circ} \mathrm{C}\right)$ in 2017.
Table 3. Effects of curing duration (c-weeks) to temperature treatment on the percentage incidence of internal necrosis in 'Covington' sweetpotatoes from an on-farm location in Middle Creek, NC in 2016.

\begin{tabular}{|c|c|}
\hline $\begin{array}{l}\text { Time (c-weeks) } \\
\text { exposed to } 75 \text { or } 82^{\circ} \mathrm{F}\end{array}$ & $\begin{array}{c}\text { Internal } \\
\text { necrosis (\%) }\end{array}$ \\
\hline No curing treatment ${ }^{\mathrm{z}}$ & 5 \\
\hline 0.5 & $2 c^{y}$ \\
\hline 1 & $6 \mathrm{~b}$ \\
\hline 2 & $10 \mathrm{ab}$ \\
\hline 3 & $12 \mathrm{a}$ \\
\hline 5 & $10 \mathrm{ab}$ \\
\hline \multicolumn{2}{|c|}{$\begin{array}{l}{ }^{2} \text { Roots not exposed to high temperature curing } \\
\text { treatment }\left[75 \text { or } 82{ }^{\circ} \mathrm{F}\left(23.9 \text { and } 27.8^{\circ} \mathrm{C}\right)\right] \text {, but } \\
\text { placed in a } 58^{\circ} \mathrm{F}\left(14.4^{\circ} \mathrm{C}\right) \text { storage room immediately } \\
\text { after harvest. Not included in analysis. } \\
{ }^{\mathrm{y}} \text { Within the column, means followed by the same } \\
\text { letter are not significantly different at } P \leq 0.05 \text { using } \\
\text { Tukey-Kramer significance difference test. }\end{array}$} \\
\hline
\end{tabular}

detected when roots were not exposed to curing temperatures; however, severity was minimal with ratings of 2 and 3 on a scale of 1 to 5 (Fig. 2). Although severity was minimal, these roots would likely be considered marketable. Incidence of IN increased as c-week increased $(2 \%, 6 \%$, and $10 \%$ IN incidence at $0.5,1$, and 2 c-week, respectively) when roots were exposed to c-temp of either 75 or $82^{\circ} \mathrm{F}$ (Table $3)$. After 2 c-weeks IN incidence leveled off and were $12 \%$ and $10 \%$ at 3 and $5 \mathrm{c}$-weeks, respectively. The increase of IN incidence in 'Covington' roots when exposed to curing (75 or $82{ }^{\circ} \mathrm{F}$ ) for longer periods of time agrees with preliminary, unpublished observations in 2015.

A significant interaction between c-temp and c-weeks at $P=0.006$ was observed at WF in 2016 (Table 2). IN incidence was higher at 2 and $5 \mathrm{c}$ weeks when roots were exposed to the 82 ( $14 \%$ incidence) vs. the $75^{\circ} \mathrm{F}$ curing treatment ( $6 \%$ incidence) ( $\mathrm{Ta}$ ble 4 ). Incidence of IN was $1 \%$ when roots were exposed to c-temps of either 75 or $82{ }^{\circ} \mathrm{F}$ for 0.5 c-weeks. Similar to the HF study, no increase in IN incidence was observed after 2 c-weeks, regardless of c-temp treatment (Table 3).

Response to treatments in the CRS study differed from the HF and WF studies, as there were a number of two-way and three-way interactions (Table 2). A significant interaction between $\mathrm{c}$-weeks and c-temp $(P=$ 0.6) was not observed in the CRS study, whereas this interaction was 
significant in the WF study $(P=$ 0.006 ). The postharvest treatments interacted with preharvest treatments where a two-way interaction (mow $x$ $c$-weeks) and a three-way interaction $($ mow $\times$ fert $\times$ c-temp $)$ were observed. In plots that were mowed, IN incidence ranged from $2 \%$ to $5 \%$ when exposed to c-temp from 0.5 to $5 \mathrm{c}$ weeks (Table 5 ). In plots that were not mowed and roots were exposed to c-temp treatments from 0.5 to $5 \mathrm{c}$ weeks, IN incidence increased from $1 \%$ to $12 \%$ compared with when foliage was not mowed. Although no statistical differences in IN incidence were measured at the other c-weeks $(0.5,1,2$, and 3$)$, a trend of IN incidence being consistently lower when vines were mowed compared with when they were not mowed was observed.

The differences in time from mowing to harvest may be an important consideration and a possible reason for the varied response to mowing in the different 2016 studies. Mowing times in these experiments varied due to rainfall that resulted in wet field conditions and therefore the harvests were delayed (mowing time before harvest was $22 \mathrm{~d}$ at CRS, whereas it was 17 and $12 \mathrm{~d}$ before harvest at WF and HF, respectively) (Table 1). Vine removal studies have confirmed that vine mowing 10 to $14 \mathrm{~d}$ before harvest is beneficial as it increases skin toughness and enhances the sweetpotato root-skin adhesion (LaBonte and Wright, 1993; Schultheis et al., 2000). A more recent study showed that use of a vine-snatcher, where vine and roots were completely separated, increased skin toughness and was achieved as early as $4 \mathrm{~d}$ after snatching, with a more significant increase after $8 \mathrm{~d}$ in 'Covington' and 'Beauregard' roots (Akula, 2019). Thus, mowing not only improves skin adhesion in sweetpotatoes, but might help reduce IN in sweetpotatoes.

Table 4. Effects of curing duration (c-weeks) and curing temperature (c-temp) or vine mowing treatment on the percentage incidence of internal necrosis in 'Covington' sweetpotatoes at WF on-farm location in Newton Grove, NC in 2016 and 2017, respectively.

\begin{tabular}{|c|c|c|c|c|}
\hline \multirow{3}{*}{$\begin{array}{l}\text { Time cured } \\
\text { (c-weeks) }\end{array}$} & \multicolumn{4}{|c|}{ Internal necrosis (\%) } \\
\hline & \multicolumn{2}{|c|}{$\begin{array}{l}2016 \text { Temp } \\
{\left[\mathrm{c}-\operatorname{temp}\left({ }^{\circ} \mathrm{F}\right)\right]}\end{array}$} & \multicolumn{2}{|c|}{$\begin{array}{c}2017 \text { Mowing } \\
\text { treatments }\end{array}$} \\
\hline & 75 & 82 & Mow & No mow \\
\hline $\mathrm{NCT}^{\mathrm{z}}$ & 0 & 0 & 0 & 0 \\
\hline 0.5 & $1 d^{y}$ & $1 \mathrm{~d}$ & $3 c^{x}$ & $3 c$ \\
\hline 1 & $2 \mathrm{bc}$ & $6 \mathrm{bc}$ & $10 \mathrm{bc}$ & $20 \mathrm{~b}$ \\
\hline 2 & $6 \mathrm{bc}$ & $14 \mathrm{a}$ & $14 \mathrm{bc}$ & $32 \mathrm{a}$ \\
\hline 3 & $9 \mathrm{ab}$ & $8 \mathrm{ab}$ & $-^{\mathrm{w}}$ & - \\
\hline$\underline{5}$ & $6 \mathrm{bc}$ & $14 \mathrm{a}$ & - & - \\
\hline \multicolumn{5}{|c|}{$\begin{array}{l}{ }^{\mathrm{z}} \mathrm{No} \text { curing treatment }(\mathrm{NCT}) \text {; roots not exposed to high temperature curing treatment }\left[75 \text { or } 82{ }^{\circ} \mathrm{F}(23.9 \text { and }\right. \\
\left.\left.27.8^{\circ} \mathrm{C}\right)\right] \text {, but placed in a } 58^{\circ} \mathrm{F}\left(14.4^{\circ} \mathrm{C}\right) \text { storage room immediately after harvest. Not included in analysis. } \\
{ }^{\circ} \text { Significant at } P \leq 0.05 \text { using the Tukey-Kramer procedure when letters differed between temperature } \times \text { time }(\mathrm{c} \text { - } \\
\text { weeks) across rows and between columns in } 2016 \text {. } \\
\text { w Significant at } P \leq 0.05 \text { using the Tukey-Kramer procedure when letters differed between mowing } \times \text { time (c-weeks) } \\
\text { across rows and between columns in } 2017 \text {. } \\
{ }^{\mathrm{w}} \mathrm{C} \text {-weeks of } 3 \text { and } 5 \text { weeks were not included in the } 2017 \text { postharvest study. }\end{array}$} \\
\hline
\end{tabular}

Fertilizer treatment in the CRS study in 2016 had a minimal role in IN incidence, although there was a significant mow $\times$ fert $\times$ c-temp interaction (Table 6). Mow or not mow treatments in which $\mathrm{K}_{2} \mathrm{SO}_{4}$ was applied were not significantly different whether c-temp was 75 or $82^{\circ} \mathrm{F}$. In one treatment with $\mathrm{KCl}$ (mow $\times$ fert $\left.\times 82{ }^{\circ} \mathrm{F}\right), \quad 11 \%$ IN incidence resulted in comparison with $5 \%$ or less for all other treatment combinations. Although fert was significant in the mow $\times$ fert $\times 82^{\circ} \mathrm{F}$ combination, c-temp, c-weeks, and mow played a more significant role in IN incidence in all of the 2016 studies (Table 2). In preliminary, unpublished observations, a higher incidence of IN occurred when $\mathrm{KCl}$ vs. $\mathrm{K}_{2} \mathrm{SO}_{4}$ was used to grow 'Covington' sweetpotatoes. We did not find the role of fert in 2016 studies to affect the incidence of IN in the HF or WF studies, with very minimal effects in the CRS study.

2017. As in the WF study in 2016, no differences between fert treatments were observed in the WF study in 2017 (Table 2). The preharvest mow treatment was significant at $P=0.004$, as was the interaction between mow $\times$ c-weeks at WF in 2017 (Table 4). Compared with the CRS study in 2016 (Table 5 ), treatment response was similar in 2017 at WF (Table 4) with IN occurrence appearing to be greater in 2017 than in the $2016 \mathrm{CRS}$ study (Table 5 ). In 2017 , for the no mow treatment, IN incidence increased from 0.5 to 1 to 2 c-weeks $(3 \%, 20 \%$, and $32 \%$, respectively) (Table 4 ). The IN incidence for mow treatments was also greater as c-weeks increased $(3 \%, 10 \%$, and $14 \%$, respectively) but was lower than the no mow treatment at 2 c-weeks. When storage roots were cured for as little as 1 c-week

Table 5. Effects of vine mowing treatment in combination with curing duration (c-weeks) on the percentage incidence of internal necrosis in 'Covington' sweetpotatoes at Cunningham Research Station in Kinston, NC in 2016 and 2017.

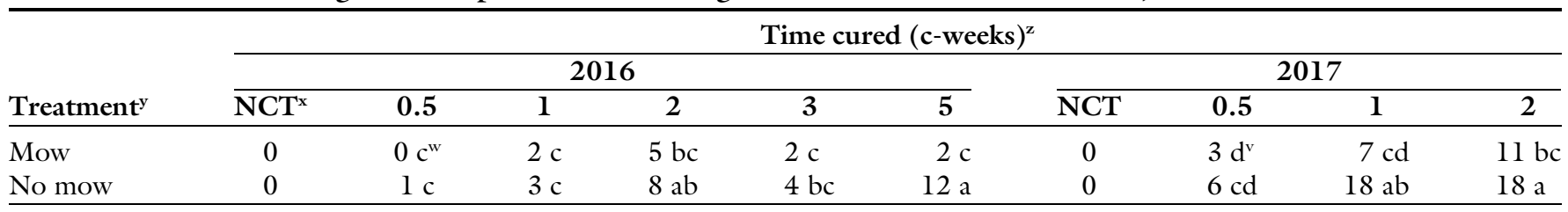

${ }^{\mathrm{z}}$ Roots exposed to high temperature curing treatment of 75 or $82{ }^{\circ} \mathrm{F}\left(23.9\right.$ and $\left.27.8^{\circ} \mathrm{C}\right)$ in 2016 or 75 or $85{ }^{\circ} \mathrm{F}\left(29.4^{\circ} \mathrm{C}\right)$ in 2017 .

${ }^{y}$ Mowing treatments included the removal of plant foliage with a crop shredder 12 and $22 \mathrm{~d}$ before harvest in 2016 , and $14 \mathrm{~d}$ before harvest in 2017 (mow) or foliage was not removed until day of harvest (no mow).

${ }^{\mathrm{x}}$ No curing treatment (NCT); roots not exposed to high temperature curing treatment but placed in a $58{ }^{\circ} \mathrm{F}\left(14.4^{\circ} \mathrm{C}\right)$ storage room immediately after harvest. Not included in analysis.

${ }^{\text {w}}$ Significant at $P \leq 0.05$ using the Tukey-Kramer procedure when letters differed between mowing treatment $\times$ time cured (c-weeks) in 2016 across rows and between columns. 'Significant at $P \leq 0.05$ using the Tukey-Kramer procedure when letters differed between mowing treatment $\times$ time cured (c-weeks) in 2017 across rows and between columns. 
compared with $0.5 \mathrm{c}$-week, the incidence of IN increased for the no mow treatment, whereas IN incidence did not increase in the mow treatment when roots were treated for 2 c-weeks. Results indicated that mowing reduced IN incidence. The main effect of c-temp also had a significant impact on IN incidence (Table $2)$, as incidence was greater (16\%) at 85 ${ }^{\circ} \mathrm{F}$ compared with $11 \%$ at $75{ }^{\circ} \mathrm{F}$ (data not shown). The importance of using an abbreviated, cooler than recommended curing treatment (Edmunds et al., 2008) in commercial facilities appears crucial to minimize IN occurrence in 'Covington'.

In the 2017 CRS study, the interactions of mow $\times$ c-temp and no mow $\times$ c-temp affected incidence of IN. The highest level of IN incidence $(21 \%)$ occurred when the vines were not mowed and the roots were cured at $85{ }^{\circ} \mathrm{F}$, whereas when vines were mowed and cured at $75{ }^{\circ} \mathrm{F}$, IN incidence was only 7\% (Table 7). However, when vines were mowed and roots were cured at $85{ }^{\circ} \mathrm{F}$, a $10 \%$

Table 6. Effects of vine mowing treatment in combination with fertilizer and curing temperature (c-temp) on the percentage incidence of internal necrosis in 'Covington' sweetpotatoes at Cunningham Research Station in Kinston, NC in 2016.

\begin{tabular}{|c|c|c|c|c|}
\hline \multirow[b]{4}{*}{$\operatorname{Temp}\left[\mathrm{c}-\operatorname{temp}\left({ }^{\circ} \mathbf{F}\right)\right]^{\mathrm{x}}$} & \multicolumn{4}{|c|}{ Mowing treatments ${ }^{\mathrm{z}}$} \\
\hline & \multirow{2}{*}{\multicolumn{2}{|c|}{$\begin{array}{c}\text { Mow } \\
\text { Fertilizer }^{\mathrm{y}}\end{array}$}} & \multirow{2}{*}{\multicolumn{2}{|c|}{$\begin{array}{l}\text { No mow } \\
\text { Fertilizer }\end{array}$}} \\
\hline & & & & \\
\hline & PS & MP & PS & MP \\
\hline 75 & $2 b^{w}$ & $2 \mathrm{~b}$ & $3 \mathrm{~b}$ & $4 \mathrm{~b}$ \\
\hline 82 & $3 \mathrm{~b}$ & $3 \mathrm{~b}$ & $5 \mathrm{~b}$ & $11 \mathrm{a}$ \\
\hline
\end{tabular}

${ }^{\mathrm{z}}$ Mowing treatments included the removal of plant foliage with a crop shredder 12 and $22 \mathrm{~d}$ before harvest (mow) or foliage was not removed until day of harvest (no mow).

${ }^{\mathrm{y}}$ Fertilizer treatments included either a high chlorine treatment [muriate of potash $(\mathrm{MP}), \mathrm{KCl}$ ] or a low chlorine treatment [potassium sulfate (PS), $\mathrm{K}_{2} \mathrm{SO}_{4}$ ] applied at 7 to $14 \mathrm{~d}$ after planting and 21 to $4 \mathrm{l} \mathrm{d}$ after planting.

${ }^{x}$ Roots exposed to high temperature curing treatment of 75 or $82{ }^{\circ} \mathrm{F}\left(23.9\right.$ and $\left.27.8{ }^{\circ} \mathrm{C}\right)$.

${ }^{w}$ Significant at $P \leq 0.05$ using the Tukey-Kramer procedure when letters differed across rows and between columns.

Table 7. Interaction of vine mowing and curing temperature (c-temp) treatments on the percentage incidence of internal necrosis in 'Covington' sweetpotatoes at Cunningham Research Station in Kinston, NC (CRS) in 2016 and 2017.

\begin{tabular}{|c|c|c|c|c|}
\hline \multirow[b]{3}{*}{ Treatment $^{\mathrm{x}}$} & \multicolumn{2}{|c|}{$2016^{\mathrm{z}}$} & \multicolumn{2}{|c|}{2017} \\
\hline & \multicolumn{4}{|c|}{$\overline{\operatorname{Te}} \mathrm{s} p\left[\mathrm{c}-\operatorname{temp}\left({ }^{\circ} \overline{\mathbf{F}}\right)\right]^{\mathrm{y}}$} \\
\hline & 75 & 82 & 75 & 85 \\
\hline Mow & $2 b^{w}$ & $3 \mathrm{~b}$ & $3 c^{v}$ & $11 \mathrm{~b}$ \\
\hline No mow & $3 \mathrm{~b}$ & $8 \mathrm{a}$ & $7 \mathrm{bc}$ & $21 \mathrm{a}$ \\
\hline
\end{tabular}

${ }^{\mathrm{z}}$ Sweetpotato roots were cured for $0.5,1,2,3$, and 5 weeks in 2016 studies and $0.5,1$, and 2 weeks in 2017 studies. $\mathrm{y}\left({ }^{\circ} \mathrm{F}-32\right) \div 1.8={ }^{\circ} \mathrm{C}$

${ }^{\mathrm{x}}$ Mowing treatments included the removal of plant foliage with a crop shredder 12 and $22 \mathrm{~d}$ before harvest in 2016 and $14 \mathrm{~d}$ before harvest in 2017 (mow), or foliage was not removed until day of harvest (no mow).

wSignificant at $P \leq 0.05$ using the Tukey-Kramer procedure when letters differed between across rows and between columns in 2016.

vignificant at $P \leq 0.05$ using the Tukey-Kramer procedure when letters differed across rows and between columns in 2017 . as to increase total soluble solids and ascorbic acid, and reduce weight loss (Herath et al., 2000). Research on sweetpotatoes in which $\mathrm{K}$ carrier and rates have been evaluated have focused on yield with various postharvest internal chemistry properties in which an excellent review is provided by Byju and George (2005), although there is no mention of the IN disorder in this publication or by other authors in other publications with respect to $\mathrm{K}$ damage to root or storage organs. In this study, any advantage or detriment of potash form was not readily apparent with respect to IN incidence in 'Covington' sweetpotato.

\section{Conclusions}

The evidence for a role of $\mathrm{K}$ fertilizer associated with IN in sweetpotatoes was not well supported in these studies, as any response was detected in only very specific conditions. Preharvest mowing resulted in less IN incidence in three of the five studies. We are not sure of the reasons why mowing before harvest was not consistent for all five studies, but suspect that mowing time before harvest and environment likely play an important role. Future work should consider vine removal practices and its timing before harvest.

No curing $\left(58{ }^{\circ} \mathrm{F}\right)$ resulted in very minimal incidence and severity of IN both years (3\% to $5 \%$ in 2016 and $0 \%$ in 2017). Curing temperatures above $80^{\circ} \mathrm{F}\left(82\right.$ or $\left.85^{\circ} \mathrm{F}\right)$ are likely to increase IN incidence. Curing duration was also critical as more IN incidence occurred when c-weeks was 1 or 2 compared with 0.5 . The effects of lowering temperatures and reducing curing time of 'Covington' appears to be critical in minimizing IN occurrence. If storage roots are held at curing temperatures $\left(75^{\circ} \mathrm{F}+\right.$ $85 \% \mathrm{RH}$ ) for less than $1 \mathrm{c}$-week, the risk of IN incidence decreases. Growers need to reduce the curing time and temperature with 'Covington' sweetpotatoes, which differs from current sweetpotato curing recommendations (Edmunds et al., 2008).

Minimal or no curing may negatively impact the storability and other quality aspects of sweetpotatoes in the long term. Although we did not specifically address the effects of reduced temperatures on disease and water loss in our research, we 
Table 8. Interaction of vine mowing, curing duration (c-weeks) and fertilizer treatments on the percentage incidence of internal necrosis in 'Covington' sweetpotatoes at Cunningham Research Station in Kinston, NC (CRS) in 2017.

\begin{tabular}{|c|c|c|c|c|c|c|c|c|}
\hline \multirow[b]{4}{*}{ Treatment $^{\mathrm{x}}$} & \multicolumn{8}{|c|}{ Fertilizer $^{\mathrm{z}}$} \\
\hline & \multicolumn{4}{|c|}{ MP } & \multicolumn{4}{|c|}{ PS } \\
\hline & \multicolumn{8}{|c|}{ Time cured (c-weeks) } \\
\hline & $\mathrm{NCT}^{\mathrm{w}}$ & 0.5 & 1 & 2 & NCT & 0.5 & 1 & 2 \\
\hline Mow & 0 & $5 \mathrm{~cd}^{\mathrm{v}}$ & $5 \mathrm{~cd}$ & $14 \mathrm{abc}$ & 0 & $2 \mathrm{~d}$ & $8 \mathrm{bcd}$ & $8 \mathrm{bcd}$ \\
\hline No mow & 0 & $5 \mathrm{~cd}$ & $22 \mathrm{a}$ & $19 \mathrm{ab}$ & 0 & $7 \mathrm{~cd}$ & $13 \mathrm{abcd}$ & $18 \mathrm{ab}$ \\
\hline
\end{tabular}

${ }^{\mathrm{z}}$ Fertilizer treatments included either a high chlorine treatment [ muriate of potash $\left.(\mathrm{MP}), \mathrm{KCl}\right]$ or a low chlorine treatment [potassium sulfate (PS), $\left.\mathrm{K}_{2} \mathrm{SO} \mathrm{O}_{4}\right]$ applied at 7 to 14 $\mathrm{d}$ after planting and 21 to $41 \mathrm{~d}$ after planting.

${ }^{y}$ Roots exposed to high temperature curing treatment of 75 or $85{ }^{\circ} \mathrm{F}\left(23.9\right.$ and $\left.29.4{ }^{\circ} \mathrm{C}\right)$.

${ }^{\mathrm{x}}$ Mowing treatments included the removal of plant foliage with a crop shredder $14 \mathrm{~d}$ before harvest (mow), or foliage was not removed until day of harvest (no mow).

wo curing treatment (NCT); roots not exposed to high temperature curing treatment but placed in a $58^{\circ} \mathrm{F}\left(14.4^{\circ} \mathrm{C}\right)$ storage room immediately after harvest. Not included in analysis.

${ }^{v}$ Significant at $P \leq 0.05$ using the Tukey-Kramer procedure when letters differed across rows and between columns.

observed very minimal disease incidence across treatments. Furthermore, we worked closely with commercial growers who had regularly encountered IN. In response to these studies, they reduced both their storage facility temperatures and curing duration normally used as per commercial recommendations (Edmunds et al., 2008) and suffered no apparent increase in sweetpotato loss due to disease, yet reduced IN incidence. A research study over a longer storage period is warranted to evaluate the effects of lowering temperature and reducing curing duration on sweetpotato roots stored over a 12 -month period. Future research should evaluate the balance between minimizing disease, and maximizing shelf life and quality of sweetpotatoes using curing time and temperature while minimizing IN.

\section{Literature cited}

Akula, A. 2019. Development, field evaluation and economic impact assessment of a mechanical aid for harvesting sweetpotatoes. PhD Thesis, North Carolina State Univ., Raleigh.

Arancibia, R.A., J.L. Main, and C.A. Clark. 2013. Sweetpotato tip rot incidence is increased by preharvest applications of ethephon and reduced by curing. HortTechnology 23:288-293.

Beam, S.C., K.M. Jennings, D.W. Monks, J.R. Schultheis, and S. Chaudhari. 2017. Influence of herbicides on the development of internal necrosis of sweetpotato (Ipomoea batatas). Weed Technol. 31:863-869.

Buescher, R.W., W.A. Sistrunk, and P.L. Brady. 1975. Effects of ethylene on metabolic and quality attributes in sweetpotato roots. J. Food Sci. 40:1018-1020.
Byju, G. and J. George. 2005. Potassium nutrition of sweet potato. Adv. Hort. Sci. 19:221-239.

Clark, C.A., W.L. Da Silva, R.A. Arancibia, J.L. Main, J.R. Schultheis, Z.Z. Pesic-Vanesbroeck, C. Jiang, and J. Smith. 2013a. Incidence of end rots and internal necrosis in sweetpotato is affected by cultivar, curing, and ethephon defoliation. HortTechnology 23:886-897.

Clark, C.A., D. Ferrin, T. Smith, and G. Holmes. 2013b. Compendium of sweetpotato diseases, pests, and disorders. 2 nd ed. Am. Phytopathological Soc., St. Paul, $\mathrm{MN}$.

Dittmar, P.J., J.R. Schultheis, K.M. Jennings, D.W. Monks, S. Chaudhari, S. Meyers, and C. Jiang. 2018. Effect of cultivar, ethephon, flooding and storage duration on sweetpotato internal necrosis. HortTechnology 28:246-250.

Dittmar, P.J., K.M. Jennings, D.W. Monks, and J.R. Schultheis. 2010. Determining the effect of ethylene on internal black marbling expression in sweetpotato. HortScience 45:488-489 (abstr.).

Edmunds, B.A., M. Boyette, C.A. Clark, D. Ferrin, T. Smith, and G. Holmes. 2008. Postharvest handling of sweetpotatoes. North Carolina Coop. Ext. Serv. AG-413-10-B .

Garner, W.W., J.E. McMurtrey, J.D. Bowling, and E.G. Moss. 1930. Role of chlorine in nutrition and growth of the tobacco plant and its effect on the quality of the cured leaf. J. Agr. Res. 40:627-648.

Herath, H.M.I., C.C. Bandara, and D.M.G. Aveysinghe Banda. 2000. Effect of calcium and potassium fertilizer applied at the time of planting on the control of internal browning under cold storage of Mauritius pineapple. Trop. Agr. Res. 12:352-359.

Jiang, C., P. Perkins-Veazie, S.M. Blankenship, M.D. Boyette, Z. Pesic-VanEsbroeck,
K.M. Jennings, and J.R. Schultheis. 2015. Occurrence, severity, and initiation of internal necrosis in 'Covington' sweetpotato. HortTechnology 25:340-348.

Kemble, J.M., L. Ivey, K.M. Jennings, and J.F. Walgenbach. 2016. Sweetpotato, p. 94-96. In: 2016 Southeastern U.S. vegetable handbook. Vance Publ., Lincolnshire, IL.

Kitinoja, L.A. 1987. Effects of low concentrations of ethylene on sweetpotatoes (Ipomoea batatas (L.) (Lam) during curing and storage. Acta Hort. 201:37-42.

LaBonte, D.R. and M.E. Wright. 1993. Image analysis quantifies reduction in sweetpotato skinning injury by preharvest canopy removal. HortScience 28:1201.

Lee, R. and J. Kpytowski. 1998. Fertilizer manual. 3rd ed. Kluwer Academic Publ., Dordrecht, The Netherlands.

Lester, G.E., J.L. Jifon, and D.J. Makus. 2010. Impact of potassium nutrition on postharvest fruit quality: Melon (Cucumis melo L) case study. Plant Soil 335:117131.

Main, J.L., M.W. Shankle, and T.F. Garrett. 2009. A comparison of ethephon and conventional vine removal systems for Mississippi sweetpotato. HortScience 44:574 (abstr.).

McCants, C.B. and W.G. Woltz. 1967. Growth and mineral nutrition of tobacco. Adv. Agron. 19:211-265.

Mosaic Company. 2020. Potassium chloride. 30 June 2020. <https://www. cropnutrition.com/resource-library/ potassium-chloride $>$.

Schultheis, J.R., S. Blankenship, D. Monks, and M. Boyette. 2000. Preharvest methods to reduce skinning in 'Beauregard' sweetpotato. HortScience 35:444 (abstr.).

Schultheis, J.R. and A.C. Thornton. 2007. Determining the expression or lack of expression of internal marbling in 
Covington roots via vegetative propagation during the growing season and in storage; Refinement of nitrogen application rate and timing to optimize yields and root sizing of Covington sweetpotato, $\mathrm{p}$. 68-78. In: North Carolina Sweetpotato Res. Ext. Ext. Rpt. 2007. North Carolina State Univ., Raleigh.

Schultheis, J.R., Z. Pesic-VanEsbroeck, K.M. Jennings, P.J. Dittmar, and A.C. Thornton. 2009. Effects of environmental stress and pathogens on the internal mottling and end rots of sweetpotato in new commercial varieties ('Hatteras' and 'Covington') and established commercial varieties ('Beauregard' and 'Carolina Rudy'), p. 77-84. In: North Carolina Sweetpotato Res. Ext. Rpt. 2009. North Carolina State Univ., Raleigh.
Skogley, F.A. 1962. Nature and mechanisms of ammonium and chloride influences on growth and properties of tobacco. MS Thesis, North Carolina State Univ., Raleigh.

Timbie, M. and N.F. Haard. 1977. Involvement of ethylene in hardcore syndrome of sweet-potato roots. J. Food Sci. 42:491-493.

U.S. Department of Agriculture. 2020. Vegetables 2019 summary. 14 Mar. 2020. <https://downloads.usda.library. cornell.edu/usda-esmis /files/ 02870v86p/0r967m63g/sn00bf58x/ vegean20.pdf $>$.
Wang, X., R.A. Arancibia, J.L. Main, and M. Shankle. 2012. Pre-harvest application of ethephon enhances skin lignification and increases the force required to peel sweetpotato storage roots. HortScience 47(9):S191 (abstr.).

Yencho, G.C., K.V. Pecota, J.R. Schultheis, Z. Pesic-Vanesbroeck, G.J. Holmes, B.E. Little, A.C. Thornton, and V. Truong. 2008. 'Covington' sweetpotato. HortScience 43:1911-1914. 